\title{
Oxytricha telomere-binding protein: separable DNA-binding and dimerization domains of the $\alpha$-subunit
}

\author{
Guowei Fang, John T. Gray, and Thomas R. Cech ${ }^{1}$ \\ Department of Chemistry and Biochemistry, Howard Hughes Medical Institute, University of Colorado, Boulder, Colorado \\ 80309-0215 USA
}

\begin{abstract}
A telomere-binding protein heterodimer of $56-\mathrm{kD}(\alpha)$ and $41-\mathrm{kD}(\beta)$ subunits binds to the single-stranded $\left(\mathrm{T}_{4} \mathrm{G}_{4}\right)_{2}$ terminus of each Oxytricha nova macronuclear DNA molecule. The $\alpha$-subunit by itself binds to telomeric DNA. The $\beta$-subunit alone does not bind to DNA specifically but interacts with the $\alpha$-subunit to form a very stable ternary complex. We show that the formation of $\alpha-\beta-D N A$ ternary complex is extremely cooperative. Furthermore, the binary complex $(\alpha-D N A)$ has a dissociation half-life of much less than 1 min; addition of the $\beta$-subunit increases the half-life to $\sim 100$ hrs. Libraries of plasmids with random deletions of the open reading frame for the $\alpha$-subunit were introduced into Escherichia coli, and extracts were subsequently checked for both protein expression and DNA-binding activity with or without added $\beta$-subunit. The $\alpha$-subunit was found to contain two structurally separable domains with distinct functions. The amino-terminal two-thirds is necessary and sufficient for sequence-specific DNA binding. The carboxy-terminal one-third is responsible for $\alpha / \beta$-subunit interactions. When expressed separately in $E$. coli, purified, and mixed together, these two domains reconstitute the activity of the wild-type $\alpha$-subunit (trans-complementation in vitro). The amino-terminal two-thirds of the $\beta$-subunit is necessary and sufficient both for $\alpha / \beta$-subunit interactions and for ternary complex formation. We conclude that the $\alpha$-subunit of the telomere-binding protein, like many transcription factors, has separable DNA-binding and protein-protein interaction domains.
\end{abstract}

[Key Words: Oxytricha; telomere-binding protein; DNA-binding domain; protein-protein interaction domain; domain complementation in trans]

Received December 14, 1992; revised version accepted March 5, 1993.

Telomeres, the ends of linear chromosomes, are essential for the stability and complete replication of eukaryotic chromosomes (for review, see Zakian 1989; Blackburn 1991). In contrast to the unstable ends generated by chromosome breakage, telomeres cap chromosomes, protecting them from degradation and end-to-end ligation (Muller 1938; McClintock 1941, 1942). Telomeric DNA is important for the complete replication of chromosomes by serving as a substrate for telomerase, a reverse transcriptase with an internal RNA template, which adds telomeric repeats to the single-stranded $3^{\prime}$ end of telomeric DNA /Greider and Blackburn 1985, 1987, 1989; Zahler and Prescott 1988; Morin 1989; Shippen-Lentz and Blackburn 1990; Yu et al. 1990; Romero and Blackburn 1991; Yu and Blackburn 1991). In addition, telomeres are involved in chromosome localization and nuclear architecture. Cytological observations suggest that chromosomes may attach to the nuclear envelope through their telomeres (Dancis and Holmquist 1979; Agard and Sedat 1983; Hochstrasser et al. 1986;

${ }^{1}$ Corresponding author.
Rawlins et al. 1991|. Biochemical evidence also shows that human telomeres are associated with the nuclear matrix (de Lange 1992). Recently, telomeres have been observed to affect the expression of adjacent genes (Gottschling et al. 1990; Aparicio et al. 1991).

Telomeric DNA consists of tandem repeats of a simple sequence with one strand rich in guanosine oriented in a $5^{\prime}$ to $3^{\prime}$ direction toward the end of the chromosome (e.g., $\mathrm{T}_{2} \mathrm{AG}_{3}$ in humans and $\mathrm{T}_{4} \mathrm{G}_{4}$ in Oxytrich $a_{\text {; for review, }}$ see Blackburn and Szostak 1984; Zakian 1989). The G-rich strand protrudes as a $3^{\prime}$ overhang of two repeat units in several evolutionarily divergent organisms examined (Klobutcher et al. 1981; Henderson and Blackburn 1989). It is therefore believed that $3^{\prime}$ single-stranded overhangs may be a general feature of telomeres.

Telomeric DNA has been found to interact with proteins in many organisms. In Oxytricha nova, a heterodimeric protein consisting of $56-\mathrm{kD}(\alpha)$ and $41-\mathrm{kD}$ (B) subunits binds specifically to the single-stranded $\mathrm{T}_{4} \mathrm{G}_{4} \mathrm{~T}_{4} \mathrm{G}_{4}$ overhang of each macronuclear DNA terminus, protecting the DNA from DNase I cleavage and specific guanine residues from dimethylsulfate (DMS) 
methylation (Gottschling and Cech 1984; Gottschling and Zakian 1986; Price and Cech 1987). The protein is tenaciously, yet noncovalently, bound to telomeric DNA, and the complex is stable under a wide range of conditions, including high salt concentrations (Gottschling and Zakian 1986; Price and Cech 1989).

Macronuclear genes encoding the $\alpha$ - and $\beta$-subunits have been cloned and sequenced (Hicke et al. 1990; Gray et al. 1991|. Each gene contains a short intron. The first exon of the $\alpha$ gene encodes a 35-amino-acid polypeptide rich in lysine. In the $\beta$ gene, the second exon encodes a lysine-rich portion of the protein; this carboxy-terminal two-thirds of the protein has slight sequence similarity to histone $\mathrm{H} 1$. The predicted amino acid sequences do not reveal any known DNA-binding motif, so the heterodimer appears to represent a novel type of DNA-binding protein. Homologous genes have been cloned and sequenced in Stylonychia mytilis, revealing $80 \%$ amino acid sequence identity between the Oxytricha and Stylonychia proteins (Fang and Cech 1991). In Euplotes, a $51-\mathrm{kD}$ telomere-binding protein has $36 \%$ amino acid sequence identity to the Oxytricha $\alpha$-subunit (Price 1990; Wang et al. 1992).

Oxytricha telomere-binding protein genes have been expressed in Escherichia coli. The recombinant $\alpha$-subunit binds to DNA by itself, giving a methylation footprint pattern ( $\alpha$ pattern) different from that of the $\alpha-\beta$ DNA complex ( $\alpha \boldsymbol{\beta}$ pattern). The $\beta$-subunit alone does not confer any methylation protection to telomeres under the same assay conditions. When mixed together with telomeric DNA, the two subunits form a complex that has the same methylation footprint pattern as telomeres in vivo (Gray et al. 1991). This ternary complex contains one molecule each of $\alpha, \beta$, and DNA (Fang and Cech 1993).

This paper reports structural studies on DNA-protein interactions and $\alpha / \beta$-subunit interactions in the telomeric complex. The recombinant $\alpha$ - and $\beta$-subunits bind DNA cooperatively, forming a complex that is extremely stable kinetically. The $\alpha$-subunit contains two separable domains with distinct functions. The DNA-binding domain resides in the amino-terminal two-thirds of the polypeptide encoded by the second exon, and the $\alpha / \beta$ interaction domain resides in the carboxy-terminal onethird. These two domains can function in trans to reconstitute wild-type $\alpha$ activity. The amino-terminal twothirds of the $\beta$-subunit is necessary and sufficient for $\beta$ to participate in the $\alpha-\beta-$ DNA complex.

\section{Results \\ $\alpha$ - and $\beta$-subunits bind to telomeric DNA cooperatively}

The DNA probe used throughout this study was a singlestranded oligonucleotide OXY2T (OXY2 tail), 40 nucleotides in length, with two telomeric $T_{4} G_{4}$ repeats at its $3^{\prime}$ end preceded by a 24-nucleotide nontelomeric sequence (tail sequence). A biotinylated version of OXY2T, referred to as BOXY2T, was used in a direct binding assay. A control probe [(BNSC) biotinylated non-specific control DNA] had the two $\mathrm{T}_{4} \bar{G}_{4}$ repeats at the $3^{\bar{t}}$ end of $\overline{\mathrm{BOXY}} 2 \mathrm{~T}$ replaced by a 16 -nucleotide tail sequence from the $5^{\prime}$ end of OXY2T. Lysates of $E$. coli expressing recombinant $\alpha$-and/or $\beta$-subunits ( $\alpha$ extract shown in Fig. 1A) were allowed to bind to biotinylated DNA in solution. DNA-protein complexes were purified from unbound proteins by use of streptavidin-paramagnetic beads and analyzed by SDS-PAGE. Because of the highly basic nature of the telomere-binding protein, lysozyme was added during the initial binding reactions as a nonspecific competitor and an internal control.

As shown in Figure 1B, the $\alpha$-subunit binds to BOXY2T better than to BNSC (cf. lanes 1 and 2), indicating the binding specificity. The $\beta$-subunit by itself binds weakly to BOXY2T and BNSC to the same extent (data not shown). When the $\alpha$ - and $\beta$-subunits are mixed together (lane 3), there is a large increase in the amount of $\alpha$ - and $\beta$-subunits bound to BOXY2T compared with the amount of either $\alpha$ - or $\beta$-subunit bound alone, suggesting a cooperativity between the two subunits in binding telomeric DNA.

The cooperativity was confirmed by quantitative filter binding experiments with purified subunits (Fig. 2A). The $\alpha$-subunit alone gives a canonical binding curve (Fig. 2B), whereas $\alpha+\beta$ gives a sigmoid binding curve (Fig. $2 \mathrm{Cl}$, diagnostic of a cooperative interaction. The level of cooperativity is reflected in the slopes of Hill plots (Fig. $2 \mathrm{~B}, \mathrm{C}$, insets $\mid$. The $\alpha$ binding is noncooperative, and the Hill plot has a slope of 1 . The $\alpha+\beta$ binding shows a slope of 2 , which indicates high cooperativity. OXY2T is bound much tighter by the $\alpha$ - and $\beta$-subunits in the ternary complex $\left[K_{\mathrm{d}}=(1.4 \mathrm{nM})^{2}=2 \mathrm{nM}^{2}\right.$; Fig. $\left.2 \mathrm{C}\right]$ than by the $\alpha$-subunit alone $\left(K_{\mathrm{d}}=125 \mathrm{nM}\right.$, Fig. $\left.2 \mathrm{~B}\right)$. The $\beta$-subunit by itself binds to telomeric DNA very weakly $\left(K_{\mathrm{d}}\right.$ approximately equal to $4 \mu \mathrm{M})$. We conclude that the binding of the one subunit facilitates the binding of the other subunit, and, together, they form a much tighter complex than either subunit alone.

The $\alpha$-DNA binary complex (which is not a single, homogeneous complex based on native gel electrophoresis; see below) and the $\alpha-\beta$-DNA ternary complex have completely different kinetic stabilities. In a cold chase experiment, purified $\alpha$ or $\alpha+\beta$ was incubated with radioactively labeled OXY2T to allow complex formation. A $5 \times 10^{4}$ - to $10^{5}$-fold excess of unlabeled OXY2T $(2.5-5$ $\mu \mathrm{M}$ ) was then added to the binding reactions to capture any dissociated proteins, and the amount of radioactive OXY2T bound to protein was analyzed as a function of time. The binary complex dissociates within $1 \mathrm{~min}$ (Fig. 2D). On the other hand, the dissociation curve for the ternary complex is biphasic. The fast dissociation, the first portion of which is apparent in Figure 2D, occurs within $35 \mathrm{~min}$ after the cold chase and accounts for $25 \%$ of the complex. The slow dissociation accounts for $75 \%$ of the complex with a half-life on the order of $100 \mathrm{hr}$ (data not shown). Cold chase experiments assayed by native gel electrophoresis with 250 -fold excess of unlabeled probe gave similar results (data not shown). 

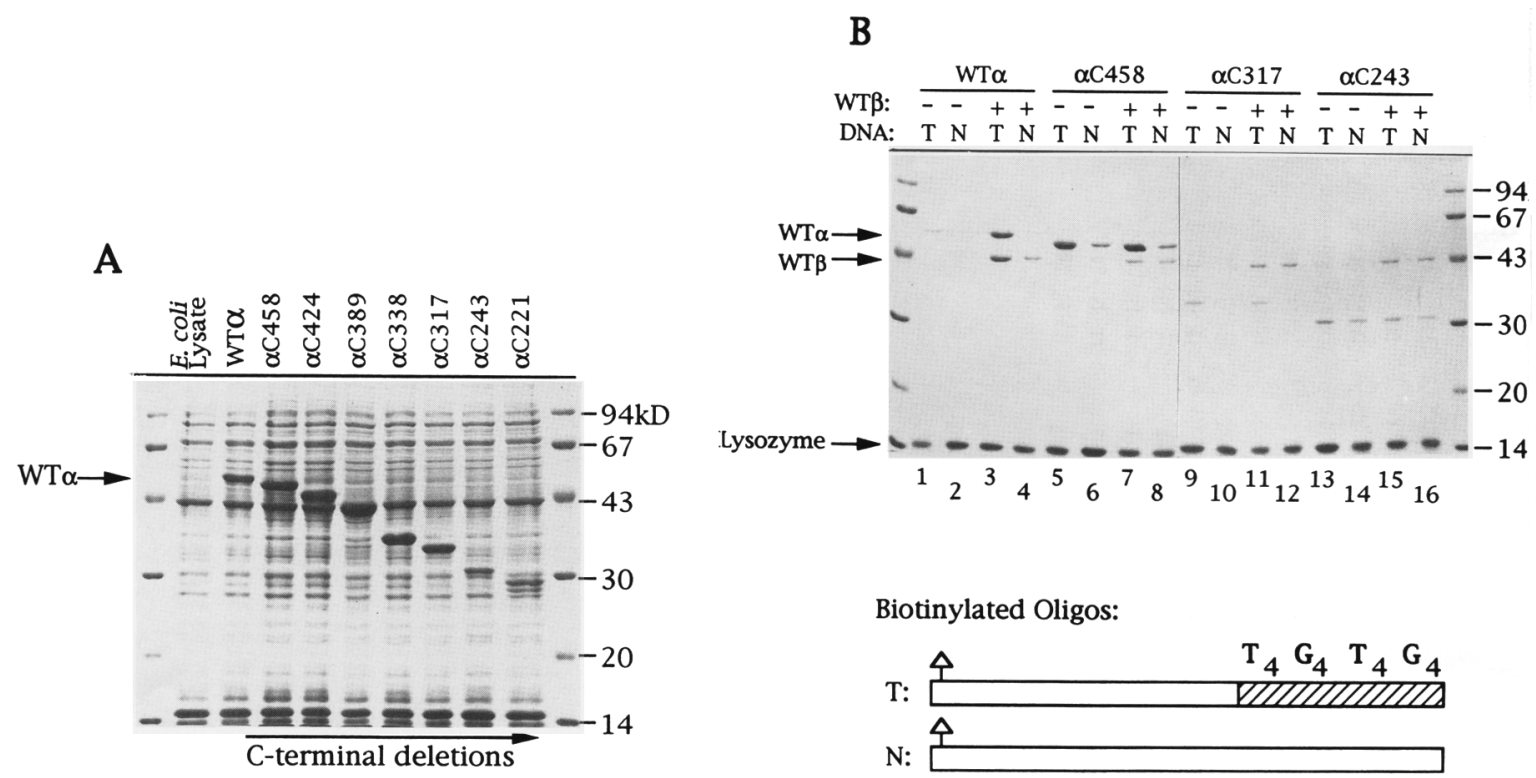

Figure 1. Expression and DNA-binding activity of mutant $\alpha$-subunits with progressively larger deletions from the carboxyl terminus (A) The expression level of wild-type (WT) and mutant proteins was analyzed by SDS-PAGE and Coomassie blue staining. (Flanking lanes) Molecular mass markers. $(B)$ Direct binding assay. E. coli lysates containing the $\alpha$-subunit or deletion mutants thereof were incubated with BOXY2T ( $T$, telomeric) or BNSC (N, nonspecific) with or without added $\beta$-subunit. DNA-protein complexes were then purified from unbound proteins using streptavidin beads. Bound protein was analyzed by SDS-PAGE and visualized by Coomassie blue staining. (Open bars) Nontelomeric DNA sequence; (triangle) biotin.

\section{Deletion libraries}

To identify regions of each polypeptide essential for formation of the telomeric complex, a deletion analysis was performed. Four deletion libraries were constructed, one for each subunit, unidirectionally deleted from either end. Colonies from each deletion library were picked randomly to screen for protein expression by SDS-PAGE (Fig. 1A). Deletion end points were determined by DNA sequencing. The nomenclature for the deletion proteins is such that the first letter represents the subunit, the second letter the terminus from which the deletion was made, and the following number the new terminal amino acid position. For example, $\alpha \mathrm{C} 317$ represents an $\alpha$-subunit deletion protein whose carboxyl terminus is at amino acid 317 instead of 495 in the intact protein. $\beta N 192$ represents a $\beta$-subunit deletion protein starting from amino acid position 192 and continuing to the wild-type carboxyl terminus. Representative mutants from each deletion library were analyzed for their DNAbinding activities and for subunit interactions by direct binding assays (Fig. 1B), mobility retardation assays (Fig. 3), and DMS methylation footprinting (Fig. 4), all performed with crude lysates from $E$. coli expressing the recombinant proteins. In addition, selected mutant proteins were purified and their DNA-binding constants determined.

The extreme carboxy-terminal region of the $\alpha$-subunit is necessary for the $\alpha / \beta$ interaction

We analyzed 172 colonies from the carboxy-terminal de- letion library for the $\alpha$-subunit, and 65 of them expressed protein well. Among these, $\alpha \mathrm{C} 207$ had the largest deletion. No well-expressed protein with a larger deletion was isolated, presumably because of the instability of such protein in $E$. coli (see Discussion). Eight represent tative mutant proteins with progressively larger deletions were analyzed in detail. In the direct binding assay, a mutant protein with a small carboxy-terminal deletion $\{\alpha \mathrm{C} 458\}$ binds to BOXY2T much better than wild-type $\alpha$-subunit \{Fig. 1B, lanes 5,1\}. Indeed, the amount of binding by $\alpha \mathrm{C} 458$ alone is comparable to the amount of bound wild-type $\alpha$ in the presence of the $\beta$-subunit (Fig. $1 B$, lanes 3,5 ). This phenomenon is termed enhanced $\alpha$ binding. $\alpha \mathrm{C} 458$, however, fails to promote binding of the $\beta$-subunit. Unlike wild-type $\alpha+\beta$ binding, where the amount of bound $\beta$-subunit is greatly increased over the background as a result of the binding cooperativity between the two subunits (Fig. 1B, lanes 3,4), the amount of bound $\beta$ in the presence of $\alpha \mathrm{C} 458$ is indistinguishable from the background (Fig. 1B, lanes 7,8). We conclude that mutant $\alpha \mathrm{C} 458$ retains sequence-specific DNA- binding activity, but fails to interact with the $\beta$-subunit to form a ternary complex.

In a mobility retardation assay, the $E$. coli lysate in the absence of telomere-binding protein does not shift radioactively labeled OXY2T during native gel electrophoresis, nor does the $\beta$-subunit or $\beta C 232$ under the assay conditions used (Fig. 3A, lanes $C$ and 1; data not shown for the intact $\beta$-subunit). The recombinant $\alpha$-subunit by itself gives a smear, consistent with the fast dissociation rate of the binary complex, and $\beta C 232$ supershifts the $\alpha-\mathrm{OXY} 2 \mathrm{~T}$ complex into a slowly migrating complex in 

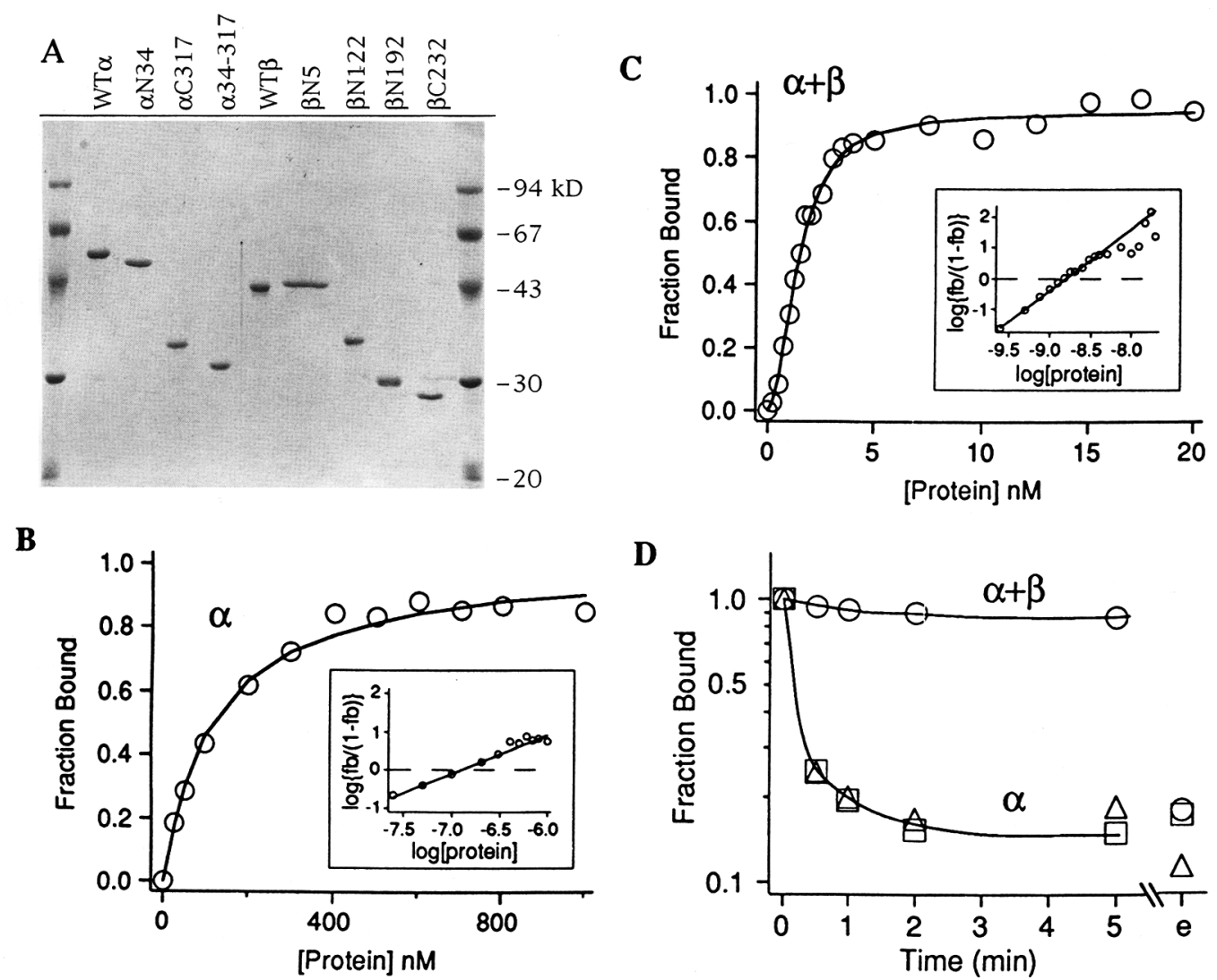

Figure 2. Binding and dissociation of telomere-binding proteins and OXY2T determined by filter binding. OXY2T is at $50 \mathrm{pM}$ in all experiments. $(A)$ SDS-polyacrylamide gel of purified telomere-binding protein and its deletion mutants. Proteins were stained with Coomassie blue. (Flanking lanes) Molecular mass markers. $\beta$ N5 migrates slower than wild-type $\beta$-subunit as a result of 12 extra amino acids fused to its amino terminus (see Materials and methods). (B) Equilibrium binding curves for $\alpha$ binding to OXY2T. The heavy line represents a theoretical curve with $K_{\mathrm{d}}=125 \mathrm{nM}$. (C) Equilibrium binding curve for $\alpha$ - and $\beta$-subunits binding to OXY2T. The concentrations of the $\alpha$ - and $\beta$-subunits were covaried, with each subunit present at the concentration indicated. The heavy line represents a theoretical binding curve with $K_{\mathrm{d}}=2 \mathrm{nM}^{2}$, a Hill coefficient of 2 , and normalized for $94 \%$ maximum binding. (Insets in $B$ and $C$ ) Hill plots of $\alpha$ and $\alpha+\beta$ binding to OXY2T. (fb) Fraction bound. The solid lines have slopes of 1 and 2 , respectively. (D) Kinetic stabilities of the binary and ternary complexes. Reactions containing $500 \mathrm{nM}$ protein and 50 pM labeled OXY2T were incubated at $37^{\circ} \mathrm{C}$ for $15 \mathrm{~min}$ prior to challenge with varying concentrations of unlabeled OXY2T. Zero time point was taken prior to competitor addition, and e represents an end point for competition obtained by mixing labeled and unlabeled OXY2T prior to the addition of proteins prel $\alpha-\beta$-DNA ternary complex challenged with $5 \mu \mathrm{M}$ cold OXY2T; ( $\square$ ) $\alpha$-DNA complex challenged with $2.5 \mu \mathrm{M}$ cold OXY2T; $(\Delta) \alpha$-DNA complex challenged with $5 \mu \mathrm{M}$ cold OXY2T.

the gel (Fig. 3A, lanes 2,3). The wild-type $\beta$-subunit supershifts the $\alpha$-OXY2T complex into the well, which is not very informative (data not shown). Like wild-type $\alpha$-subunit, $\alpha \mathrm{C} 458$ alone binds to OXY2T, giving one major and several minor shifted bands (Fig. 3B, lane 6). But $\beta C 232$ does not supershift $\alpha \mathrm{C} 458-\mathrm{OXY} 2 \mathrm{~T}$ complexes (Fig.3B, lane 7), indicating lack of interaction between $\alpha \mathrm{C} 458$ and $\beta \mathrm{C} 232$. A slight increase in the amount of OXY2T shifted in the presence of $\beta C 232$ (cf. lanes 6 and 7) is particular to this experiment and not reproducible.

In a DMS methylation footprint assay, the wild-type $\alpha$-subunit alone protects G2 and G4 of BOXY2T while enhancing methylation of G3 (Fig. 4A; Fig. 4B, cf. lanes 1 and $C$ ). This footprint pattern is called $\alpha$ pattern (Fig. 4A). Under the higher salt conditions used here, the $\alpha$ pattern involves only the $3^{\prime}$ telomeric repeat /cf. Gray et al. 1991). Consistent with the data from direct binding and mobility retardation assays, the $\beta$-subunit alone does not confer any methylation protection for BOXY2T under these assay conditions (Fig. 4B, lane 2). A new footprint pattern called the $\alpha \beta$ pattern is created in the presence of both $\alpha$ - and $\beta$-subunits (Fig. 4A,B, lane 3; Gray et al. 1991). Here, the $\alpha$ pattern seems to translate to the second $\mathrm{G}_{4}$ block with $\mathrm{G} 9, \mathrm{G} 10$, and $\mathrm{G} 12$ protected and G11 slightly enhanced. In the first $\mathrm{G}_{4}$ block, G2-G4 are all protected with the heaviest protection on G3. This $\alpha \beta$ pattern is indistinguishable from that of telomeres in vivo (Price and Cech 1987). The $\alpha \mathrm{C} 458$ protein confers the $\alpha$ pattern to BOXY2T both in the presence and in the absence of the $\beta$-subunit (Fig. 4B, lanes 14,15), which confirms the results from direct binding and mobility retardation assays: $\alpha \mathrm{C} 458$ retains sequence-specific DNA-binding activity, but fails to interact with the $\beta$-subunit. 
A

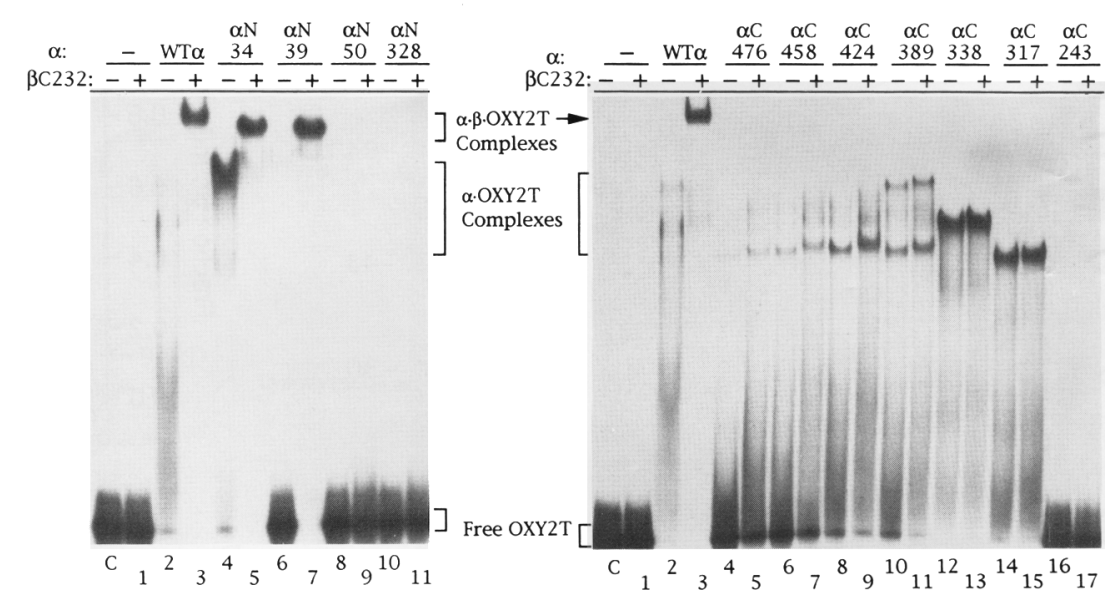

Figure 3. Mobility retardation assay. E. coli lysates containing the $\alpha$-subunit of the telomere-binding protein, amino-terminal deletion mutants $(A)$, and carboxy-terminal deletion mutants $(B)$ were incubated with 5 '-labeled OXY2T with or without added $\beta \mathrm{C} 232$. Complexes were then analyzed by native $10 \%$ PAGE. (Lane C) Control lysate of $E$. coli transformed with expression vector.
Like $\alpha \mathrm{C} 458$, mutants $\alpha \mathrm{C} 476, \alpha \mathrm{C} 424, \alpha \mathrm{C} 389, \alpha \mathrm{C} 338$, and $\alpha \mathrm{C} 317$ all retain sequence-specific DNA-binding activity but fail to interact with the $\beta$-subunit in all three assays (Fig. 1B, lanes 9-12; Fig. 3B, lanes 4,5, 8-15; Fig. 4B, lanes 12,13, 16-23; summarized in Fig. 5A). As the

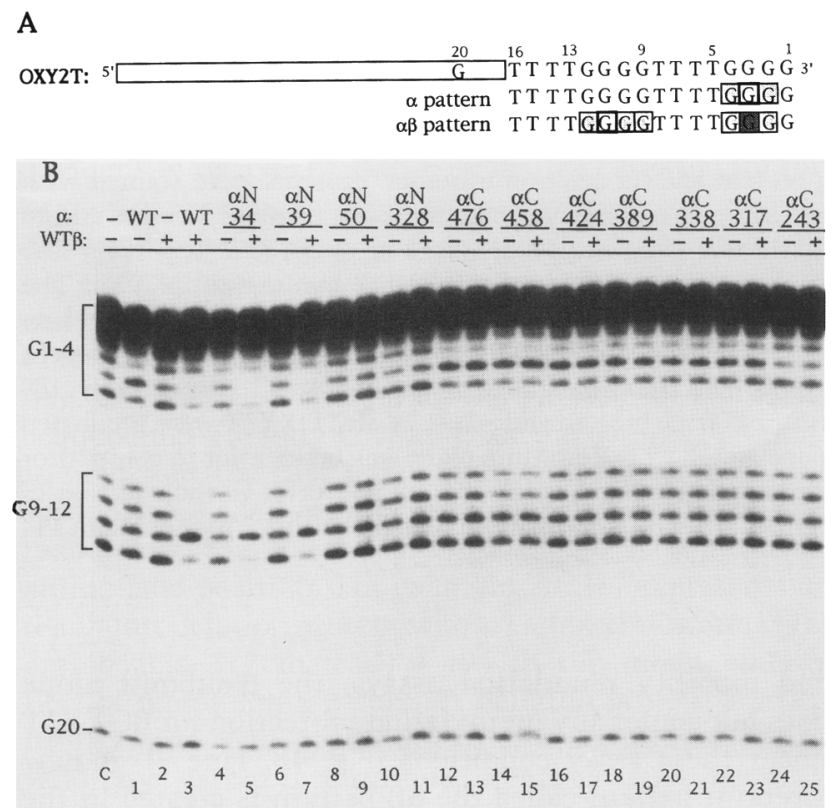

Figure 4. DMS methylation footprint assay. $|A|$ Schematic representation of the methylation footprint patterns generated by the $\alpha$-subunit alone and by $\alpha+\beta$. The nucleotide numbering of OXY2T is shown at the top of the DNA sequence. Open squares represent enhanced methylation and cleavage. Squares with light and dark shading represent moderate and heavy protection from methylation, respectively. $(B)$ The 5 '-labeled BOXY2T was incubated with wild-type (WT) or mutant $\alpha$-subunit in $E$. coli lysates with or without added $\beta$-subunit, and then subjected to DMS methylation and pyrrolidine cleavage. The methylation footprint patterns were analyzed by urea-PAGE. (G20) A G residue in the tail sequence, which serves as an internal control for loading differences. (Lane $C$ ) Control lysate of $E$. coli transformed with expression vector. proteins get smaller, they form $\alpha$-DNA complexes that band well, and the number of complexes decreases in the mobility retardation assay (Fig. 3B, lanes $4-15$ ). Mutants $\alpha \mathrm{C} 476$ and $\alpha \mathrm{C} 424$ show less enhanced $\alpha$-binding activity compared with $\alpha \mathrm{C} 458$ in the direct binding assay (data not shown). Mutants $\alpha \mathrm{C} 389$, $\alpha \mathrm{C} 338$, and $\alpha \mathrm{C} 317$ do not display any enhanced $\alpha$-binding activity (Fig. 1B, lanes 9-12; data not shown). Analysis of this group of mutant proteins supports the conclusion that the extreme carboxy-terminal region of the $\alpha$-subunit is important for interactions with the $\beta$-subunit and leads us to conclude that the carboxy-terminal one-third of the protein is dispensible for formation of the $\alpha$-DNA complex.

For quantitation of DNA-binding constants, $\alpha \mathrm{C} 317$ and $\beta C 232$ were purified essentially to homogeneity (Fig. 2A). Wild-type $\alpha$ and $\alpha \mathrm{C} 317$ have comparable DNA binding affinity $\left(K_{d}=125-150 \mathrm{nM}_{\text {; }}\right.$ Fig. $\left.5 \mathrm{~A}\right)$ as assayed by a fast filtration method (see Materials and methods). No DNA binding by either wild-type $\alpha$-subunit or $\alpha \mathrm{C} 317$ was detected in a slow filtration experiment because of the fast dissociation rates of the binary complex /data not shown). There is, however, a $4 \times 10^{5}$-fold difference for these two proteins in terms of ternary complex formation as assayed by the slow filtration method. The dissociation constant is $2.6 \mathrm{nM}^{2}$ for wild-type $\alpha+\beta \mathrm{C} 232$ and $>10^{6} \mathrm{~nm}^{2}$ for $\alpha \mathrm{C} 317+\beta \mathrm{C} 232$ (Fig. 5A). This is consistent with the lack of interaction between $\alpha \mathrm{C} 317$ and $\beta C 232$.

With further deletion $(\alpha \mathrm{C} 243$ and $\alpha \mathrm{C} 221)$, mutant proteins lose DNA-binding activity (Fig. 3B, lanes 16,17; Fig. 4B, lanes 24,25; summarized in Fig. 5A). In the direct binding assay, both $\alpha \mathrm{C} 243$ and $\alpha \mathrm{C} 221$ bind to BOXY2T slightly better than to BNSC (Fig. 1A, lanes 13-16; data not shown). On the basis of these observations, we conclude that the carboxy-terminal boundary of the DNAbinding domain of the $\alpha$-subunit lies between residues 243 and 317.

The amino acids encoded by the first exon of the $\alpha$-subunit gene are dispensable

We screened 292 colonies from the amino-terminal de- 
A

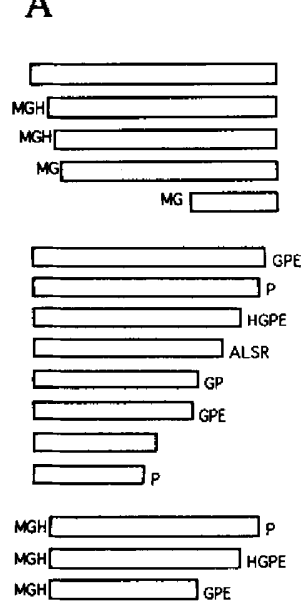

$\frac{\text { Mutant }}{W T}$ E
$\alpha N 34$
$\alpha N 39$
$\alpha N 50$
$\alpha N 328$
$\alpha C 476$
$\alpha C 458$
$\alpha C 424$
$\alpha C 389$
$\alpha C 338$
$\alpha C 317$
$\alpha C 243$
$\alpha C 221$
$\alpha 34-458$
$\alpha 34-424$
$\alpha 34-317$

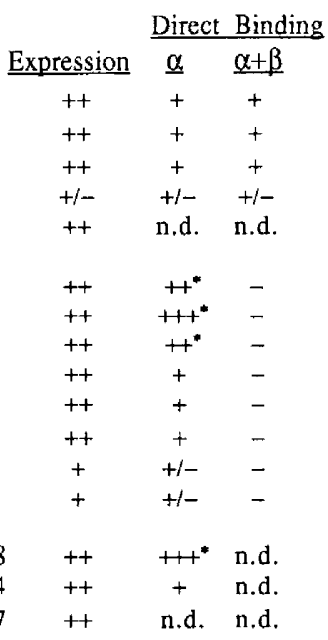

\begin{tabular}{ccc} 
Gel & Shift \\
\hline$\underline{\alpha}$ & $\underline{\alpha+\beta}$ \\
+ & + \\
+ & + \\
+ & + \\
- & - \\
- & - \\
+ & - \\
+ & - \\
+ & - \\
+ & - \\
+ & - \\
+ & - \\
- & - \\
- & - \\
+ & n.d. \\
+ & n.d. \\
+ & n.d.
\end{tabular}

\begin{tabular}{cc}
$\alpha$ & \multicolumn{2}{c}{ Protectio } \\
$\alpha$ & $\underline{\alpha+\beta}$ \\
$\alpha$ & $\alpha \beta$ \\
$\alpha$ & $\alpha \beta$ \\
$\alpha$ & $\alpha \beta$ \\
- & - \\
- & - \\
$\alpha$ & $\alpha$ \\
$\alpha$ & $\alpha$ \\
$\alpha$ & $\alpha$ \\
$\alpha$ & $\alpha$ \\
$\alpha$ & $\alpha$ \\
$\alpha$ & $\alpha$ \\
- & - \\
- & - \\
& \\
$\alpha$ & $\alpha$ \\
$\alpha$ & $\alpha$ \\
$\alpha$ & $\alpha$
\end{tabular}

\begin{tabular}{cc}
\multicolumn{2}{l}{$\underline{ }$} \\
$\alpha(\mathrm{nM})$ \\
125 & $\frac{\alpha+\beta C 232\left(\mathrm{nM}^{2}\right)}{2.6}$ \\
71 & 81
\end{tabular}

$150>106$

$620>106$

Figure 5. (A) Summary of the deletion analysis of the $\alpha$-subunit. The unauthentic amino acids resulting from deletion constructions are shown. (*) Enhanced $\alpha$ binding; (n.d.) not determined. $(B)$ Schematic representation of the domain structure of the $\alpha$-subunit. (Chy) Chymotrypsin cutting site.

letion library of the $\alpha$-subunit. Only 18 of them express mutant proteins well, and most of these contain small deletions in the first exon which encodes 35 amino acids. Deletion of the first 38 amino acids $(\alpha \mathrm{N} 39)$ still gives the wild-type level of expression. Deletion of another 11 amino acids $\{\alpha \mathrm{N} 50\}$, however, reduces the expression level by at least fourfold (data not shown). Surprisingly, a mutant with a very large amino-terminal deletion of 327 amino acids $(\alpha \mathrm{N} 328)$ is expressed efficiently. We did not recover any mutants between $\alpha \mathrm{N} 50$ and $\alpha \mathrm{N} 328$.

Four mutants were analyzed in detail. Direct binding and mobility retardation assays show that $\alpha \mathrm{N} 34$ and $\alpha \mathrm{N} 39$ are active in sequence-specific DNA-binding and $\alpha / \beta$ interactions [cooperative DNA binding in the direct binding assay (data not shown); supershift in the mobility retardation assay in the presence of the $\beta$-subunit (Fig. 3A, lanes 4-7)]. In the mobility retardation assay, aN39 alone binds to OXY2T weakly (lane 6), but it is very active in forming the ternary complex (lane 7). In the methylation footprint assay, $\alpha$ N34 and $\alpha \mathrm{N} 39$ alone confer weak $\alpha$ patterns to BOXY2T (Fig. 4B, lanes 4,6 ). They create full $\alpha \beta$ patterns in the presence of the $\beta$-subunit (Fig. 4B, lanes 5,7 ). On the other hand, mutants $\alpha \mathrm{N} 50$ and $\alpha \mathrm{N} 328$ are completely inactive in OXY2T binding [Fig. 3A, lanes 8-11; Fig. 4B, lanes 8-11; for direct binding assay (data not shown)]. A quantitative study with purified proteins (Fig. 2A) showed that $\alpha \mathrm{N} 34$ binds twofold tighter than wild-type $\alpha$-subunit (Fig. 5A). Both wild-type $\alpha$ and $\alpha \mathrm{N} 34$ interact with $\beta$ C232, but $\alpha$ N34 has 30-fold lower binding affinity in terms of ternary complex formation (Fig. 5A).
On the basis of these experiments, we conclude that the amino-terminal 35 amino acids encoded by the first exon of the $\alpha$-subunit gene are dispensable for sequencespecific DNA binding and $\alpha / \beta$-subunit interactions. The data for $\alpha \mathrm{N} 50$ are difficult to interpret because of the low expression level of this protein.

\section{a34-317 defines a sequence-specific DNA-binding domain}

Because $\alpha \mathrm{N} 34$ is active in binding to OXY2T, we constructed double-deletion variants $\alpha 34-458, \alpha 34-424$, and a34-317 to further define the DNA-binding domain. All three mutants are active in binding to OXY2T in the direct binding and mobility retardation assays (Fig. 5A). In the methylation footprint assay, they confer $\alpha$ patterns to BOXY2T both in the absence and in the presence of the $\beta$-subunit, indicating the lack of $\alpha / \beta$ interactions (Fig. 5A). This is consistent with the data from the carboxy-terminal deletion analysis. A quantitative binding study with purified proteins (Fig. 2A) also showed that $\alpha 34-317$ is active in OXY2T binding $\left(K_{\mathrm{d}}=620 \mathrm{nM}\right)$ but inactive in ternary complex formation $\left(K_{\mathrm{d}}>10^{6} \mathrm{~nm}^{2}\right)$ (Fig. 5A). Together with the deletion analysis data from both termini, these data support the conclusion that amino acids $34-317$ of the $\alpha$-subunit are necessary and sufficient for sequence-specific DNA binding. Therefore, a34-317 defines the DNA-binding domain.

Carboxy-terminal $\alpha / \beta$ interaction domain of the $\alpha$ subunit can function in trans

We have shown that the amino-terminal two-thirds of 
the $\alpha$-subunit contains the DNA-binding activity but fails to interact with the $\beta$-subunit. The carboxy-terminal region is important for the $\alpha / \beta$ interactions. We constructed a mutant protein $(\alpha \mathrm{N} 328)$ representing the carboxy-terminal one-third of the $\alpha$-subunit. $\alpha \mathrm{N} 328 \mathrm{ex}$ presses and solubilizes well but lacks any detectable DNA-binding activity. To test whether the DNA-binding domain and the $\alpha / \beta$ interaction domain can function in trans, $\alpha \mathrm{C} 338$ (DNA-binding domain) and $\alpha \mathrm{N} 328(\alpha / \beta$ interaction domain) were purified and incubated together with the $\beta$-subunit and OXY2T. In a methylation footprint assay, $\alpha \mathrm{C} 338$ alone gives an $\alpha$ pattern (Fig. 6A, lane 4). $\alpha \mathrm{N} 328, \beta$, or the combination of $\alpha \mathrm{N} 328$ and $\beta$ does not protect OXY2T from methylation (Fig. 6A, lanes 5,6,9). Combinations of $\alpha \mathrm{C} 338$ and $\alpha \mathrm{N} 328$ and of $\alpha \mathrm{C} 338$ and $\beta$ still give $\alpha$ patterns $\{$ Fig. $6 \mathrm{~A}$, lanes 7,8 ). Only when $\alpha \mathrm{C} 338, \alpha \mathrm{N} 328$, and $\beta$ are present together is the $\alpha \beta$ pattern recreated (Fig. 6A, lane 10). Figure 6B shows a titration experiment where the concentrations of $\alpha \mathrm{C} 338$ and $\beta$ were fixed and an increasing amount of $\alpha \mathrm{N} 328$ was added. A transition from the $\alpha$ pattern (lane 1 , in the absence of $\alpha \mathrm{N} 328$ ) to the complete $\alpha \beta$ pattern (lanes 5-7) is observed. The $\alpha \beta$ pattern is also observed in the presence of $\alpha \mathrm{C} 317, \alpha \mathrm{N} 328$, and $\beta$ and in the presence of $\alpha 34-317, \alpha \mathrm{N} 328$, and $\beta$. Thus, we have demonstrated

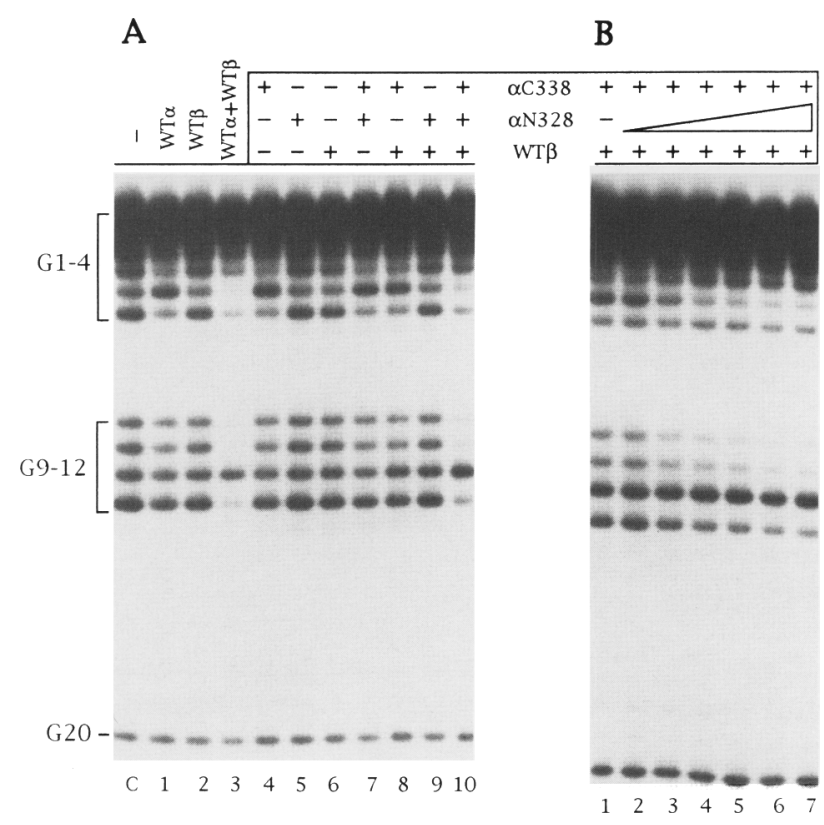

Figure 6. Domain complementation in trans as assayed by methylation footprinting. $(A)$ Methylation footprint patterns for the $\beta$-subunit, the DNA-binding and $\alpha / \beta$ interaction domains of the $\alpha$-subunit, and combinations thereof. $|\alpha C 338|$ DNA-binding domain $(2 \mu \mathrm{M})$. $(\alpha \mathrm{N} 328) \alpha / \beta$ interaction domain $(20 \mu \mathrm{M})$ (OXY2T $=200 \mathrm{nM} ; \beta=20 \mu \mathrm{M}$ ). Binding reactions were carried out for $2.5 \mathrm{hr}$ at $37^{\circ} \mathrm{C}$ in the presence of $10 \mu \mathrm{M} \mathrm{NSC}$ in $10 \mu \mathrm{l}$ of $25 \mathrm{~mm}$ HEPES (pH 7.5), $1 \mathrm{~mm}$ EDTA, and $300 \mathrm{~mm} \mathrm{NaCl}$. (Lane $C)$ No protein control. $(B)$ Concentration titration of $\alpha \mathrm{N} 328$ in a domain complementation experiment. (Lanes 1-7) 0, 0.1, 0.5, $2,5,10$, and $20 \mu \mathrm{M} \alpha \mathrm{N} 328$. Assay conditions are the same as in $A$. that the carboxy-terminal one-third of the $\alpha$-subunit is a structural entity capable of interactions with the $\beta$-subunit.

Size-exclusion chromatography analysis showed no interaction between $\alpha \mathrm{C} 338$ and $\alpha \mathrm{N} 328$ in the absence of DNA. After $\alpha \mathrm{C} 338$ and $\alpha$ N328 were incubated together for $5 \mathrm{hr}$ at $50 \mu \mathrm{M}$ concentration, the sample was subjected to size-exclusion chromatography (Superdex 75, Pharmacia). These two proteins eluted independently, each with its own characteristic retention time. The same is true for $\alpha \mathrm{N} 328$ and the $\beta$-subunit (data not shown).

So far, we have shown that the $\alpha$-subunit contains two separable domains with distinct functions: the aminoterminal two-thirds of the polypeptide encoded by the second exon for DNA binding and the carboxy-terminal one-third for $\alpha / \beta$ subunit interactions. The carboxy-terminal domain functions as a bridge to bring the $\beta$-subunit and the DNA-binding domain of the $\alpha$-subunit together to assemble a correct telomeric complex. Proteinprotein interactions do not appear to take place in the absence of telomeric DNA.

\section{The amino-terminal two-thirds of the $\beta$-subunit is necessary and sufficient for telomeric complex formation}

We screened 99 colonies from the carboxy-terminal deletion library of the $\beta$-subunit. Twenty-seven of them expressed protein well. These 27 mutants contain progressively larger deletions from the carboxyl terminus up to residue 232 . Like the full-length $\beta, \beta C 232$ does not by itself protect BOXY2T from methylation, but gives the $\alpha \beta$ pattern when combined with the $\alpha$-subunit (Fig. 7A). In the mobility retardation assay, $\beta C 232$ supershifts the $\alpha$-DNA complex into a discrete slow-migrating band (Fig. 3A, lane 3), instead of shifting the DNA into the wells as does the wild-type $\beta$-subunit (data not shown). $\beta C 232$ also shows cooperativity with the $\alpha$-subunit in the direct binding assay and in the filter-binding assay (data not shown; summarized in Fig. 8A). Purified $\beta$ and $\beta C 232$ proteins are comparable in ternary complex formation when judged by quantitative filter binding $\left(K_{\mathrm{d}}=2 \mathrm{nM}^{2}\right.$ for $\alpha+\beta$ and $2.6 \mathrm{nM}^{2}$ for $\left.\alpha+\beta C 232\right)$. Thus, the amino-terminal two-thirds of the $\beta$-subunit $(\beta C 232)$ is sufficient both for the $\alpha / \beta$ interaction and for telomeric complex formation.

Of 141 colonies screened from the amino-terminal deletion library of the $\beta$-subunit, only 13 expressed proteins well. These 13 mutants fall into three groups according to the size of the deletion. Three mutant proteins representative of these groups, $\beta N 5, \beta N 122$, and $\beta N 192$, were analyzed in detail. Like the wild-type $\beta$-subunit, none of these by itself protects BOXY2T from DMS methylation (Fig. 7B, lanes $1,3,5$ ). $\beta N 5$ interacts with the $\alpha$-subunit to create an $\alpha \beta$ pattern (Fig. 7B, lane 2 ). When $\beta$ N122 or $\beta N 192$ was incubated with the $\alpha$-subunit, however, only the $\alpha$ pattern was observed, indicating a lack of $\alpha / \beta$ interactions (Fig. 7B, lanes 4,6 ). These results are consistent with data from the direct binding 


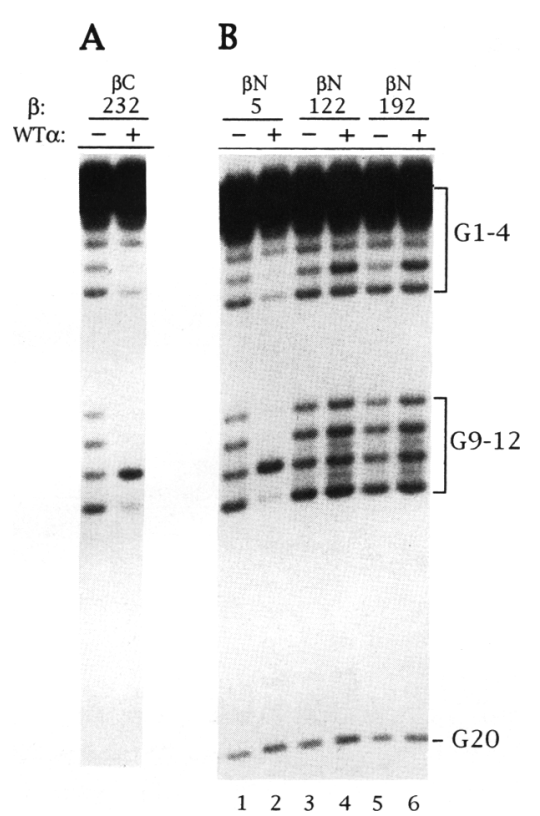

Figure 7. DMS methylation footprint assay. The 5'-labeled BOXY2T was incubated with deletion mutants of the $\beta$-subunit in $E$. coli lysates with or without added $\alpha$-subunit and then subjected to DMS methylation and pyrrolidine cleavage. The methylation footprint patterns were analyzed by urea-PAGE. (G20) A G residue in the tail sequence that serves as an internal control for loading differences.

assay (data not shown). In the mobility retardation assay, wild-type $\beta$ and $\beta$ N5 supershift the $\alpha$-DNA complex into wells of the native gel, and $\beta N 122$ and $\beta$ N192 do not supershift the $\alpha$-DNA complex (data not shown; summarized in Fig. 8A).

Quantitative binding studies with purified proteins (Fig. 2A) support these qualitative conclusions. $\beta N 5$ and wild-type $\beta$ are comparable in ternary complex formation $\left(K_{\mathrm{d}}=5.7 \mathrm{~nm}^{2}\right.$ for $\alpha+\beta N 5$ and $2 \mathrm{nM}^{2}$ for $\left.\alpha+\beta\right)$. $\beta N 122$ and $\beta N 199$ are inactive in ternary complex formation $\left(K_{\mathrm{d}}>2.5 \times 10^{5} \mathrm{nM}^{2}\right.$ in both cases $)$. Thus, the amino-terminal region of the $\beta$-subunit is necessary for $\alpha / \beta$ interactions and for telomeric complex formation.

\section{Discussion}

\section{Cooperative binding of $\alpha$ - and $\beta$-subunits}

In $O$. nova, a heterodimeric protein consisting of $\alpha$ - and $\beta$-subunits binds to the single-stranded DNA at each macronuclear telomere. The $\alpha$-subunit, the $\beta$-subunit, and telomeric DNA form a $1: 1: 1$ ternary complex /telomeric complex), which has a DMS methylation footprint pattern indistinguishable from that of telomeres in vivo (Gray et al. 1991; Fang and Cech 1993). We have now shown that the $\alpha$ - and $\beta$-subunits bind to telomeric DNA cooperatively by the following criteria. In the direct binding assay, there is a large increase in the amount of bound protein in the presence of both subunits compared with that of either subunit alone. Quantitative binding studies confirm that $\alpha$ - and $\beta$-subunits bind much tighter than either $\alpha$ - or $\beta$-subunits alone $\left(K_{\mathrm{d}}=2 \mathrm{nM}^{2}\right.$ for $\alpha+\beta$, $125 \mathrm{nM}$ and $4 \mu \mathrm{M}$ for $\alpha$ and $\beta$ alone, respectively). The $\alpha+\beta$-binding curve is sigmoid with a Hill coefficient of 2 , consistent with completely cooperative binding between the two subunits.

We can envision two different physical models to explain the binding cooperativity between the two subunits. The $\alpha$ - and $\beta$-subunits may interact directly with each other in the ternary complex; therefore, the binding is tighter than with either subunit alone. In a second model that is not mutually exclusive of the first, the binding of one subunit could change the DNA conformation in a way that facilitates the binding of the second subunit. For example, the binding of one subunit could stabilize a DNA hairpin structure necessary for the binding of the other subunit. Mutual enhancement of binding through a DNA conformation change could also explain the cooperativity. Data from protein cross-linking experiments support the first model (Fang and Cech 1993). The $\alpha$ - and $\beta$-subunits were cross-linked as a heterodimer in the ternary complex. In addition, dimerization is DNA dependent. In the absence of telomeric DNA, the two subunits failed to cross-link to each other by all three reagents tested. DNA-dependent dimerization is sufficient to explain the sigmoid nature of the $\alpha+\beta$ binding curve.

The binary $(\alpha-\mathrm{DNA})$ and the ternary $(\alpha-\beta-\mathrm{DNA})$ complex have completely different kinetic stability. The half-life for the binary complex is much less than $1 \mathrm{~min}$. The dissociation curve for the ternary complex is biphasic. The fast dissociating species accounts for $25 \%$ of the complex and dissociates within $35 \mathrm{~min}$. The half-life for the slow dissociating ternary complex is on the order of $100 \mathrm{hr}$. The biphasic dissociation behavior has also been observed in the telomere-binding protein purified from O. nova (Raghuraman and Cech 1989). Protein-DNA complexes have a wide range of half-lives: $<1 \mathrm{sec}$ for $\mathrm{T} 4$ gene 32 protein-DNA complexes (Lohman 1984); a few minutes for the lactose repressor-operator DNA complex (Whitson and Matthews 1986); and on the order of $10 \mathrm{hr}$ for RNA polymerase-T7 promoter complexes (Cech and McClure 1980). The 100-hr half-life observed for the telomeric complex is very long in this context. We conclude that the addition of the $\beta$-subunit greatly stabilizes the telomeric complex.

\section{Deletion library strategy}

To identify portions of the telomere-binding protein involved in particular functions, we constructed libraries of both amino- and carboxy-terminal deletions of each subunit. Colonies were picked randomly from each library to screen for protein expression. The number of colonies screened was large enough to give a high probability that every 20-amino-acid window was sampled from both termini for each subunit (see Materials and methods). Thus, the failure to recover some categories of deleted proteins, such as mutants deleted beyond residue 207 from the carboxyl terminus of the $\alpha$-subunit, prob- 
Figure 8. (A) Summary of the deletion analysis of the $\beta$-subunit. The small hatched boxes represent the first 12 amino acids from phage $\mathrm{T} 7$ gene 10 protein fused to the amino termini of the deletion proteins. Additional unauthentic amino acids resulting from the deletion construction are shown. $\left(^{*}\right)$ All of these assays were done in the presence of the wild-type $\alpha$-subunit. (\#) Complexes stayed in the well of the native gel. $(B)$ Schematic representation of $\beta$-subunit structure.
A

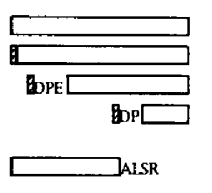

$\begin{array}{ccc}\text { Mutant } & \text { Expression } & \text { Direct Binding* } \\ \text { WT } & ++ & + \\ \beta N 5 & + & + \\ \beta N 122 & ++ & - \\ \beta N 192 & ++ & - \\ \beta C 232 & ++ & +\end{array}$

I=MASMTGGOOMGR

B

DMS Protection $^{*}$
$\alpha \beta$
$\alpha \beta$
$\alpha$
$\alpha$
$\alpha \beta$

$\frac{\mathrm{Kd}\left(\mathrm{nM}^{2}\right)^{*}}{2}$

5.7

$>2.5 \times 105$

$>2.5 \times 10^{5}$

2.6

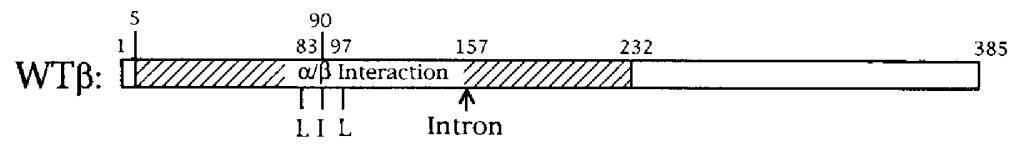

ably results from their instability in $E$. coli. Because the random deletion approach requires large-scale screening, a protein expression and extraction method was developed that allowed a single worker to analyze 60-70 colonies per day for protein expression.

\section{$\beta$-Subunit}

The carboxy-terminal, lysine-rich, one-third of the $\beta$-subunit can be deleted without any detectable effect on telomeric complex formation. A previous study of the telomere-binding protein from $O$. nova showed that the $\beta$-subunit was degraded to a $26-\mathrm{kD}$ fragment under some purification conditions (Gottschling and Zakian 1986; Price and Cech 1987). The $\alpha$-subunit and 26-kD fragment from Oxytricha remain bound to telomeric DNA in the presence of $2 \mathrm{M} \mathrm{NaCl}$ during the purification. Amino acid sequence analysis identifies the $26-\mathrm{kD}$ fragment as the amino-terminal fragment of the $\beta$-subunit $(B$. Hicke and T.R. Cech, unpubl.), consistent with our present deletion analysis of the recombinant protein. $\beta C 232$ is essentially a recombinant form of the $26-\mathrm{kD}$ fragment. Our mobility retardation, methylation footprinting, and dissociation constant data show further that this amino-terminal domain is necessary and sufficient for $\alpha / \beta$ interaction and telomeric complex formation (Fig. 8B).

What, then, is the function for the highly basic carboxy-terminal one-third of the $\beta$-subunit? The wild-type ternary complex stays in the well of a native gel, whereas deletion of the carboxy-terminal one-third of $\beta$-subunit allows the complex to migrate into the gel as a monomeric ternary complex. Although this might simply indicate that the carboxy-terminal one-third of the $\beta$-subunit promotes aggregation, it could also indicate its involvement in the formation of a higher order structure of the telomeric complex (Raghuraman and Cech 1989; Hicke et al. 1990) and in the association of telomeres in vivo (Holmquist and Dancis 1979; Lipps et al. 1982; Prescott 1983).

\section{$\alpha$-Subunit}

The $\alpha$-subunit contains two structurally separable do- mains with distinct functions. The amino-terminal twothirds of the polypeptide encoded by the second exon is necessary and sufficient for sequence-specific DNA binding. The carboxy-terminal one-third is responsible for $\alpha / \beta$-subunit interactions (Fig. $5 \mathrm{~B}$ ). J. Ruggles and S. Schultz (pers. comm.) have shown that chymotrypsin cuts the recombinant $\alpha$-subunit only once after overnight incubation, between amino acids 324 and 325 . Because this site corresponds to the carboxy-terminal end of the DNA-binding domain that we have identified, the functional domains appear to be domains of protein structure as well. A $51-\mathrm{kD}$ telomere-binding protein purified from Euplotes also contains a trypsin-resistant 35$\mathrm{kD}$ amino-terminal domain responsible for DNA binding (Price et al. 1992).

The telomere-binding protein therefore shows an unanticipated resemblance to a number of proteins involved in transcriptional regulation, such as $\lambda$ repressor, GAL4, and CAP protein, which have separate DNA-binding and protein-protein interaction domains (Pabo and Sauer 1984, 1992; Brent and Ptashne 1985; Keegan et al. 1986). However, unlike transcription regulators, which function only when two domains are tethered together in cis, the DNA-binding and protein-protein interaction domains of the $\alpha$-subunit can function in trans to reconstitute the wild-type activity. This presumably requires substantial noncovalent interactions between the two domains. In addition, the interactions between these two domains and between the $\beta$-subunit and the carboxyterminal domain of the $\alpha$-subunit are DNA dependent.

$\alpha 34-317$ is the smallest polypeptide that retains sequence-specific DNA-binding activity. UV cross-linking between the telomere-binding protein and site-specific 5 -BrdU-substituted OXY2T in the ternary complex identifies three amino acid residues of the $\alpha$-subunit in close contact with DNA; all three residues lie within the DNA-binding domain described here (B. Hicke, M. Willis, T. Koch, and T.R. Cech, in prep.).

Deletion analysis shows that the extreme carboxyl terminus of the $\alpha$-subunit is critical for $\alpha / \beta$ dimerization. Sequence analysis reveals three heptad repeats with hydrophobic residues at every seventh amino acid in this 
region (L461, L468, V475; Fig. 5B). This region is conserved between the Oxytricha and Stylonychia telomere-binding proteins (Fang and Cech 1991). Secondary structure analysis (Garnier et al. 1978) and coiled-coil structure prediction (Lupas et al. 1991) reveal that this region can potentially form an $\alpha$-helix (data not shown). Interestingly, the $\beta$-subunit also contains a short heptad repeat region $\{\mathrm{L} 83$, I90, L97; Fig. $8 \mathrm{~B})$. Thus, the $\alpha / \beta$-subunit interactions might be mediated through the heptad repeats found in both subunits. $\alpha \mathrm{C} 476$, which has the intact heptad repeats, however, does not interact with the $\beta$-subunit. This might indicate the existence of other interactions between the two subunits in addition to the proposed coiled-coil interaction. The previous proposal (Fang and Cech 1991) that three heptad repeats around residue 100 of the $\alpha$-subunit might be involved in heterodimer formation no longer appears likely on the basis of our new deletion analysis.

The small carboxy-terminal deletions $\{\alpha \mathrm{C} 476, \alpha \mathrm{C} 458$, and $\alpha \mathrm{C} 424 \mid$ cause enhanced $\alpha$ binding. The enhanced binding is also observed with a DNA probe containing only one $T_{4} G_{4}$ repeat at its 3 ' end (data not shown). The direct binding assay analyzes the amount of protein directly bound or indirectly associated with the DNA probe through protein-protein interactions or aggregation. Thus, although enhanced binding could indicate high affinity for BOXY2T, it could also indicate unnatural protein-protein interactions caused by the deletion.

How might our structural analysis provide insight about the function of the Oxytricha telomere-binding protein? We have shown that the two subunits bind to DNA in a highly cooperative manner. The ternary complex is extremely stable with a half-life of $>4$ days. This can be correlated with the in vivo protective function. On the other hand, the interactions between the two subunits are DNA dependent. Thus, once one subunit is displaced from the ternary complex, the whole complex falls apart as a result of the kinetic instability of the binary complex. This may allow entry of other proteins that interact with telomeres, such as telomerase, which elongates the 3 ' termini of chromosomes.

\section{Materials and methods \\ Oligonucleotides}

OXY2T (5'-AAGACGACATCGCTCAGCCAGACATTTTGGGGTTTTGGGG-3') and nonspecific control (NSC) (5'.AAGACGACATCGCTCAGCCAGACAGACGACATCGCTCAGC-3') were made on an Applied Biosystems 380B DNA synthesizer. BOXY2T and BNSC have the second adenines from the $5^{\prime}$ ends of OXY2T and NSC replaced by biotin residues by use of a biotin-on phosphoramidite (Clonetech).

\section{Construction of deletion libraries}

Plasmids p55A and p4lA are expression plasmids for the $\alpha$ - and $\beta$-subunit genes derived from pT5T (Eisenberg et al. 1990; Gray et al. 1991). Unidirectional deletions from the amino and carboxyl termini of each subunit were constructed by exonuclease III digestion (Putney et al. 1981; Henikoff 1984). For the aminoterminal deletion of the $\alpha$-subunit, an oligonucleotide cassette,
AATTGAAGGAGGAACTGTAAATGGGCCATGGCGAGTCACGTCCATGGCCCATTGATCCG, was inserted into the unique EcoRI site upstream from the start codon of the $\alpha$-subunit gene in the p55A. The insertion creates two NcoI sites and maintains the downstream EcoRI site. In addition, the cassette also introduces a stop codon, TAA, and a start codon, ATG (both italicized), and a ribosomal binding site GGAGG (underlined) to restore the translational coupling in the final deletion constructs. The resulting plasmid was digested with $\mathrm{NcoI}$, and ends were filled in with [ $\alpha$-thio]dNTP using the Klenow fragment of DNA polymerase I. After phenol extraction and ethanol precipitation, the plasmid was digested with EcoRI. Exonuclease III and nuclease SI digestions and subsequent ligation were performed according to the manufacturer's instructions (Erase-abase system, Promega). A time course with $30-\mathrm{sec}$ intervals was taken for the exonuclease III digestion, and the extent of digestion was analyzed by agarose gel electrophoresis to ensure a continuous distribution of deletion size.

To construct the amino-terminal deletions of the $\alpha$ - and $\beta$-subunits as fusion proteins /gene 10 protein/telomere-binding protein), the second BamHI site downstream from the open reading frames in both $\mathrm{p} 55 \mathrm{~A}$ and $\mathrm{p} 41 \mathrm{~A}$ was removed by partial digestion with BamHI. The resulting plasmids were cut with $B a m H I$ and digested with exonuclease III over a time course. The single-stranded DNA was removed by nuclease S1, and ends were blunted by Klenow fragment. After ligation of the BamHI linker (CGGGATCCCG), the remaining coding sequence was released by BamHI and KpnI digestion and ligated into the BamHI/KpnI-digested pT5T vector. In these constructs, the amino-terminal-deleted $\alpha^{-}$and $\beta$-subunits were expressed as fusion proteins with the first 12 amino acids of the phage $\mathrm{T} 7$ gene 10 protein at their amino termini, which were encoded by plasmid pT5T.

To construct deletions from the carboxyl terminus of each subunit, an oligonucleotide cassette containing stop codons in all three open reading frames and HindIII and $\mathrm{NcoI}$ sites was inserted into the unique $K p n I$ site downstream from the coding sequence in both $\mathrm{p} 55 \mathrm{~A}$ and $\mathrm{p} 41 \mathrm{~A}$. The resulting plasmids were digested with $N$ coI, and ends were filled in with [ $\alpha$-thio]dNTP. The plasmids were then digested with HindIII, and deletion libraries were constructed according to the manufacturer's instructions (Erase-a-base system, Promega).

\section{Screening of deletion libraries for protein expression}

The deletion plasmid libraries were transformed into $E$. coli BL21(DE3), and colonies were picked randomly to test for protein expression. Fifty microliters of overnight culture was freshly inoculated into $4 \mathrm{ml}$ of LB plus $12.5 \mu \mathrm{g} / \mathrm{ml}$ tetracycline, grown at $37^{\circ} \mathrm{C}$ for $2.5 \mathrm{hr}$, and induced with $0.1 \mathrm{~mm}$ IPTG. The culture was then transferred to room temperature and allowed to grow for another 4-5 hr. Cells were harvested, frozen and thawed once. Cell pellets were resuspended in $125 \mu \mathrm{l}$ of buffer A $150 \mathrm{~mm}$ HEPES at $\mathrm{pH} 7.5,0.33 \mathrm{mg} / \mathrm{ml}$ of lysozyme, $2 \mathrm{mM}$ EDTA, $10 \mathrm{~mm}$ DTT, $0.1 \mathrm{mM}$ PMSF, and $0.1 \mathrm{mM}$ TPCK), and incubated for $10 \mathrm{~min}$ at room temperature and for $10 \mathrm{~min}$ on ice to lyse cells. After the addition of $125 \mu$ l of buffer $\mathrm{B}(1 \mathrm{M} \mathrm{NaCl}$, $0.08 \%$ sodium deoxycholate, $0.1 \mathrm{mM}$ PMSF, and $0.1 \mathrm{mM}$ TPCK) and incubation for $2 \mathrm{hr}$ on ice to extract proteins, the cell debris was centrifuged at $16,000 \mathrm{~g}$ for $2 \mathrm{hr}$ at $4^{\circ} \mathrm{C}$. The supernatant $(6 \mu \mathrm{l})$ was assayed by SDS-PAGE to determine the level of protein expression, and the remaining supernatant was stored at $-20^{\circ} \mathrm{C}$ for activity assays. The exact deletion boundary was determined by DNA sequencing. DNA and amino acid sequences of the $\alpha$-subunit agreed with those reported by Gray et al. $\{1991\}$, but the number of each amino acid is one less between amino acids 
40 and 496 as a result of a typographical error in the previous publication (e.g., the carboxy-terminal tyrosine is now amino acid 495).

\section{Criteria for completeness of deletion library screening}

Two criteria were used to determine the screening size. The first one is based on statistical calculation. If we set a fixed window along a protein sequence and require a certain probability $(P \mid$ to isolate a deletion mutant protein that either ends (in the case of carboxy-terminal deletion) or starts (in the case of amino-terminal deletion) in a particular window, the number $(N)$ of colonies needed to be screened from a unidirectional deletion library can be calculated as follows: $N=\ln (1-P) /$ $\ln |1-f\rangle$, where $f=$ window size/protein size. We screened 172 and 99 colonies from the carboxy-terminal deletion libraries of the $\alpha$ - and $\beta$-subunits, respectively. We also analyzed 292 and 141 colonies from the amino-terminal deletion libraries of the $\alpha$ - and $\beta$-subunits for protein expression. Considering that every one out of three colonies randomly screened from the aminoterminal deletion libraries has an in-frame fusion to restore the correct open reading frame, we have effectively screened 97 and 47 colonies from the amino-terminal deletion libraries for protein expression. The length of the $\alpha$ - and $\beta$-subunits are 495 and 385 amino acids, respectively. Thus, we have probabilities of 0.999 and 0.995 that our screening includes at least one mutant that ends in any given 20-amino-acid window for the carboxyterminal deletions of the $\alpha$ - and $\beta$-subunits, respectively. In the case of amino-terminal deletion screening, the probabilities are 0.98 and 0.92 . The second criterion to ensure the completeness of library screening is the repeated isolation of the same deletion mutants. We have isolated multiple mutants from random screening of each primary library that end or start at the same amino acids or within a 5-amino-acid distance.

Deletion mutants were not found to be evenly spaced across each subunit. For example, we did not isolate any amino-terminal deletion mutants of the $\alpha$-subunit that started between amino acids 50 and 328 . It is possible that stable secondary structures around the translational initiation site could have been introduced by the amino-terminal deletions (Tessier et al. 1984; Buell et al. 1985). However, a second amino-terminal deletion library of the $\alpha$-subunit, constructed so that each $\alpha$ sequence was preceded by the first 12 amino acids from the T7 gene 10 protein, still gave no well-expressed mutant proteins starting between amino acids 50 and 328 . Thus, the lack of mutants in this region is not a result of inefficient translational initiation. Instead, it is likely that such mutant polypeptides are degraded in $E$. coli.

\section{Protein purification}

Equilibrium binding and dissociation experiments and the domain trans-complementation experiments were performed with highly purified $\alpha, \alpha \mathrm{C} 338, \alpha \mathrm{C} 317, \alpha \mathrm{N} 34, \alpha \mathrm{N} 328, \alpha 34-317$, $\beta, \beta C 232, \beta N 5, \beta N 122$, and $\beta N 192$. E. coli BL21(DE3) bearing p55A, p41A, or plasmids encoding deletion proteins were grown at $37^{\circ} \mathrm{C}$ in $750 \mathrm{ml}$ of $2 \times \mathrm{YT}$ with $0.1 \%$ glucose, $20 \mathrm{mM} \mathrm{K}_{2} \mathrm{HPO}_{4}$ (pH 7.0), and $12.5 \mu \mathrm{g} / \mathrm{ml}$ of tetracycline until the cell density reached $1 \mathrm{OD}_{610}$. Cells were then transferred to room temperature, grown, and induced with $0.1 \mathrm{~mm}$ IPTG at $1.5 \mathrm{OD}_{610}$. Cells were harvested $4 \mathrm{hr}$ after induction, frozen and thawed once, and resuspended in $75 \mathrm{ml}$ of HEND-150 $(50 \mathrm{mM}$ HEPES at $\mathrm{pH}$ $7.5,1 \mathrm{~mm}$ EDTA, $150 \mathrm{mM} \mathrm{NaCl}$, and $10 \mathrm{~mm}$ DTT), except for aN328. A small amount of lysozyme was added to the cell suspension and incubated for $10 \mathrm{~min}$ at room temperature and for $30 \mathrm{~min}$ on ice. Then cells were lysed by sonication and cleared by centrifugation. The supernatant was precipitated with 35$75 \%$ ammonium sulfate on ice. The pellet was resuspended in $10 \mathrm{ml}$ of HEND-150 and dialyzed overnight against 1 liter of HEND-150 at $4^{\circ} \mathrm{C}$. FPLC cation exchange chromatography (SP column from Waters) and size-exclusion chromatography ( $\mathrm{Su}$ perdex 75 from Pharmacial were performed as described previously (Gray et al. 1991).

For purification of $\alpha \mathrm{N} 328$, the cell pellet was resuspended in $75 \mathrm{ml}$ of PEND-150 (50 mM Na $2 \mathrm{HPO}_{4}$ at $\mathrm{pH} 7.5,1 \mathrm{mM}$ EDTA, $150 \mathrm{~mm} \mathrm{NaCl}$, and $10 \mathrm{~mm}$ DTT) instead of HEND-150. After precipitation with $35 \%$ ammonium sulfate, the supernatant was loaded onto a 50-ml phenyl-sepharose column (Pharmacia) and eluted with a linear gradient of $35-0 \%$ ammonium sulfate in PEND-150. Peak fractions of $\alpha$ N328 were pooled and dialyzed overnight against 1 liter of HEND-10 (25 mM HEPES at pH 7.5, $1 \mathrm{mM}$ EDTA, $10 \mathrm{~mm} \mathrm{NaCl}$, and $2 \mathrm{~mm}$ DTT) at $4^{\circ} \mathrm{C}$. FPLC cation exchange chromatography and size-exclusion chromatography were performed essentially as described previously (Gray et al. 1991). Protein concentrations were determined by UV absorbance (Gill and von Hippel 1989) or by Bradford colorimetric assay (Bio-Rad protein assay, Bio-Rad).

\section{Direct binding assay}

BOXY2T or BNSC (20 pmoles) was incubated with $6 \mu$ of telomere-binding protein or its deletion mutants in crude $E$. coli lysate in the presence of $1 \mathrm{nmole}$ of NSC, $0.1 \mathrm{mg}$ of lysozyme in $20 \mu \mathrm{l}$ of $25 \mathrm{~mm}$ HEPES (pH 7.5), 1 mM EDTA, and $300 \mathrm{~mm} \mathrm{NaCl}$ for $30 \mathrm{~min}$ at room temperature. Then $20 \mu \mathrm{l}$ of streptavidinparamagnetic beads (Promega) in incubation buffer was added. After incubating for another $30 \mathrm{~min}$, the beads were pelleted, washed twice with incubation buffer, resuspended in $15 \mu \mathrm{l}$ of SDS-PAGE sample loading buffer, and assayed by $12 \%$ SDSPAGE. Proteins were stained by Coomassie blue.

\section{Mobility retardation assay}

5 '-Labeled OXY2T $(0.2$ pmole) was incubated with $1 \mu$ l of telomere-binding protein or its deletion mutants in crude $E$. coli lysates in the presence of $5 \mu \mathrm{g}$ of hydrolyzed herring sperm DNA (Sigma) and 50 pmoles of NSC in $10 \mu \mathrm{l}$ of $25 \mathrm{~mm}$ HEPES (pH 7.5), $1 \mathrm{~mm}$ EDTA, and $50 \mathrm{~mm} \mathrm{NaCl}$ for $90 \mathrm{~min}$ at room temperature. The samples were prepared for gel electrophoresis by adding $2 \mu \mathrm{l}$ of $50 \%$ glycerol, $0.01 \%$ bromphenol blue, and $0.01 \%$ xylene cyanol. Samples $(4 \mu \mathrm{l})$ were loaded onto a $10 \%$ polyacrylamide (55:1 acrylamide/bis-acrylamide) gel that had been prerun at $15 \mathrm{~mA}$ for $30 \mathrm{~min}$. Electrophoresis was carried out for $4 \mathrm{hr}$ at $4^{\circ} \mathrm{C}$ and $15 \mathrm{~mA}$ in $0.5 \times \mathrm{TBE}$. The gel was dried and subjected to autoradiography.

\section{DMS methylation footprint assay}

5 '-Labeled BOXY2T (4 pmoles) was incubated with $6 \mu$ l of telomere-binding protein or its deletion mutants in crude $E$. coli lysates in the presence of 1 nmole of NSC, $0.1 \mathrm{mg}$ of lysozyme in $20 \mu \mathrm{l}$ of $25 \mathrm{~mm}$ HEPES (pH 7.5), $1 \mathrm{mM}$ EDTA, and $300 \mathrm{~mm}$ $\mathrm{NaCl}$ for $30 \mathrm{~min}$ at room temperature. Then $20 \mu \mathrm{l}$ of streptavidin-paramagnetic beads (Promega) in incubation buffer was added. After incubating for another $30 \mathrm{~min}, 4 \mu \mathrm{l}$ of $1 \%$ DMS was added and incubated for $10 \mathrm{~min}$ at room temperature. The methylation reactions were stopped by the addition of $8 \mu$ of stop solution $\mid 1 \mu \mathrm{g} / \mu \mathrm{l}$ yeast RNA, $0.1 \mathrm{M}$ EDTA, $2.5 \mathrm{M} \beta$-mercaptoethanol, and $0.5 \%$ SDS in TE). The streptavidin beads were then pelleted and washed once with incubation buffer and once with TE. Methylated DNA on the beads was cleaved in $50 \mu \mathrm{l}$ of $1 \mathrm{M}$ pyrrolidine for $15 \mathrm{~min}$ at $90^{\circ} \mathrm{C}$ and dried in the speed vacuum 
(Savant). DNA was eluted from the beads using $95 \%$ formamide and assayed by $12 \%$ polyacrylamide $8 \mathrm{M}$ urea gel electrophoresis. The methylation footprint assay with purified proteins was performed as described previously (Gray et al. 1991).

\section{Filter-binding assay}

Varying amounts of purified telomere-binding protein and its deletion mutants were incubated with 5 '-labeled OXY2T 150 $\mathrm{pM}$ ) in binding buffer (25 mM HEPES at pH 7.5, 1 mM EDTA, 300 $\mathrm{mm} \mathrm{NaCl}, 0.01 \%$ Tween 20 ). $\alpha-\beta-\mathrm{DNA}$ complexes were allowed to form for $24-48 \mathrm{hr}$ at $37^{\circ} \mathrm{C}$ prior to filtration. $\alpha-\mathrm{DNA}$ complexes were incubated $15-30 \mathrm{~min}$ at $37^{\circ} \mathrm{C}$. Binding reactions were filtered using the Schleicher $\&$ Schuell minifold dot blot apparatus. Reaction mix $\{20 \mu l)$ was applied to each well and rinsed with binding buffer. Two flow rates were used. For $\alpha$-subunit assays, where the dissociation rate is high, filtration was at $\sim 10-20 \mu \mathrm{l} / \mathrm{sec}$ (fast filtration). For the highly stable $\alpha-\beta-$ DNA complexes, flow rates of $1-4 \mu \mathrm{l} / \mathrm{sec}$ gave better data (slow filtration|. Radioactivity on the nitrocellulose sheets, with up to 48 individual assays each, was quantitated using the Molecular Dynamics PhosphorImager.

\section{Acknowledgments}

We thank Brian Hicke, Steve Schultz, and James Ruggles for communicating unpublished data, and Steve Schultz and James Ruggles for helpful suggestions on protein purification. We also thank Brian Hicke for a critical reading of the manuscript. This research was supported by a grant from the National Institutes of Health (GM28039). T.R.C. is an Investigator of the Howard Hughes Medical Institute and an American Cancer Society Professor.

The publication costs of this article were defrayed in part by payment of page charges. This article must therefore be hereby marked "advertisement" in accordance with 18 USC section 1734 solely to indicate this fact.

\section{References}

Agard, D.A. and J.W. Sedat. 1983. Three-dimensional architecture of a polytene nucleus. Nature 302: 676-681.

Aparicio, O., B. Billington, and D. Gottschling. 1991. Modifiers of position effects are shared between telomeric and silent mating-type loci in S. cerevisiae. Cell 66: 1279m1288.

Blackburn, E.H. 1991. Structure and function of telomeres. $\mathrm{Na}$ ture 350: 569-573.

Blackburn, E.H. and J.W. Szostak. 1984. The molecular structure of centromeres and telomeres. Annu. Rev. Biochem. 53: $163-194$.

Brent, R. and M. Ptashne. 1985. A eukaryotic transcriptional activator bearing the DNA specificity of a prokaryotic repressor. Cell 43: 729-736.

Buell, G., M.F. Schulz, G. Selzer, A. Chollet, N.R. Movva, D. Semon, S. Escanez, and E. Kawashima. 1985. Optimizing the expression in $E$. coli of a synthetic gene encoding somatomedin-C (IGF-I). Nucleic Acids Res. 13: 1923-1938.

Cech, C.L. and W.R. McClure. 1980. Characterization of ribonucleic acid polymerase-T7 promoter binary complexes. Biochemistry 19: 2440-2447.

Dancis, B.M. and G.P. Holmquist. 1979. Telomere replication and fusion in eukaryotes. J. Theor, Biol. 78: 211-224.

de Lange, T. 1992. Human telomeres are attached to the nuclear matrix. EMBO J. 11: 717-724.

Eisenberg, S.P., R.J. Evans, W.P. Arend, E. Verderber, M.T.
Brewer, C.H. Hannum, and R.C. Thompson. 1990. Primary structure and functional expression from complementary DNA of human interleukin-1 receptor antagonist. Nature 343: 341-346.

Fang, G. and T.R. Cech. 1991. Molecular cloning of telomerebinding protein genes from Stylonychia mytilis. Nucleic Acids Res. 19: 5515-5518.

-1993. Oxytricha telomere-binding protein: DNA-dependent dimerization of the $\alpha$ and $\beta$ subunits. Proc. Natl. Acad. Sci. (in press).

Garnier, J., D.J. Osguthorpe, and B. Robson. 1978. Analysis of the accuracy and implications of simple methods for predicting the secondary structure of globular proteins. J. Mol. Biol. 120: $97-120$.

Gill, S.C. and P.H. von Hippel. 1989. Calculation of protein extinction coefficients from amino acid sequence data. Anal. Biochem. 182: 319-329.

Gottschling, D.E. and T.R. Cech. 1984. Chromatin structure of the molecular ends of Oxytricha macronuclear DNA: Phased nucleosomes and a telomeric complex. Cell 38: 501510.

Gottschling D.E., and V.A. Zakian. 1986. Telomere proteins: Specific recognition and protection of the natural termini of Oxytricha macronuclear DNA. Cell 47: 195-205.

Gottschling, D., O. Aparicio, B. Billington, and V. Zakian. 1990. Position effect at $S$. cerevisiae telomeres: Reversible repression of Pol II transcription. Cell 63: 751-762.

Gray, J.T., D.W. Celander, C.M. Price, and T.R. Cech. 1991. Cloning and expression of genes for the Oxytricha telomerebinding protein: Specific subunit interactions in the telomeric complex. Cell 67: 807-814.

Greider, C.W. and E.H. Blackburn. 1985. Identification of a specific telomere terminal transferase activity in Tetrahymena extracts. Cell 43: 405-413.

- 1987. The telomere terminal transferase of Tetrahymena is a ribonucleoprotein enzyme with two kinds of primer specificity. Cell 51: 887-898.

1989. A telomeric sequence in the RNA of Tetrahymena telomerase required for telomere repeat synthesis. Nature 337: 331-337.

Henderson, E.R. and E.H. Blackburn. 1989. An overhanging 3' terminus is a conserved feature of telomeres. Mol. Cell. Biol. 9: 345-348.

Henikoff, S. 1984. Unidirectional digestion with exonuclease III creates targeted breakpoints for DNA sequencing. Gene 28: 351-359.

Hicke, B.J., D.W. Celander, G.H. MacDonald, C.M. Price, and T.R. Cech. 1990. Two versions of the genes encoding the 41-kilodalton subunit of the telomere-binding protein of $O x$ ytricha nova. Proc. Natl. Acad. Sci. 87: 1481-1485.

Hochstrasser, M., D. Mathog, Y. Gruenbaum, H. Saumweber, and J.W. Sedat. 1986. Spatial organization of chromosomes in the salivary gland nuclei of Drosophila melanogaster. $I$. Cell Biol. 102: 112-123.

Holmquist, G.P. and B. Dancis. 1979. Telomere replication, kinetochore organizers, and satellite DNA evolution. Proc. Natl. Acad. Sci. 76: 4566-4570.

Keegan, L., G. Gill, and M. Ptashne. 1986. Separation of DNA binding from the transcription-activating function of a eukaryotic regulatory protein. Science 231: 699-704.

Klobutcher, L.A., M.T. Swanton, P. Donini, and D.M. Prescott. 1981. All gene-sized DNA molecules in four species of hypotrichs have the same terminal sequence and an unusual $3^{\prime}$ terminus. Proc. NatI. Acad. Sci. 78: 3015-3019.

Lipps, H.J., W. Gruissem, and D.M. Prescott. 1982. Higher order DNA structure in the macronuclear chromatin of the hypo- 
trichous ciliate Oxytricha nova. Proc. Natl. Acad. Sci. 79: 2495-2499.

Lohman, T.M. 1984. Kinetics and mechanism of dissociation of cooperatively bound T4 gene 32 protein-single-stranded nucleic acid complexes. 1. Irreversible dissociation induced by sodium chloride concentration jump. Biochemistry 23: $4656-4665$.

Lupas, A., M. Van Dyke, and J. Stock. 1991. Predicting coiled coils from protein sequences. Science 252: 1162-1164.

McClintock, B. 1941. The stability of broken ends of chromosomes in Zea mays. Genetics 26: 234-282.

- 1942. The fusion of broken ends of chromosomes following nuclear fusion. Proc. Natl. Acad. Sci. 28: 458-463.

Morin, G.B. 1989. The human telomere terminal transferase enzyme is a ribonucleoprotein that synthesizes TTAGGG repeats. Cell 59: 521-529.

Muller, H.J. 1938. The remaking of chromosomes. Collecting Net-Woods Hole 13: 181-198.

Pabo, C.O. and R.T. Sauer. 1984. Protein-DNA recognition. Annu. Rev. Biochem. 53: 293-321.

- 1992. Transcription factors: Structural families and principles of DNA recognition. Annu. Rev. Biochem. 61: $1053-1095$.

Prescott, D.M. 1983. The C-value paradox and genes in ciliated protozoa. Mod. Cell Biol. 2: 329-352.

Price, C.M. 1990 . Telomere structure in Euplotes crassus: Characterization of DNA-protein interactions and isolation of a telomere-binding protein. Mol. Cell. Biol. 10: 3421-3431.

Price, C.M. and T.R. Cech. 1987. Telomeric DNA-protein interactions of Oxytricha macronuclear DNA. Genes \& Dev. 1: 783-793.

1989. Properties of the telomeric DNA-binding protein from Oxytricha nova. Biochemistry 28: 769-774.

Price, C.M., R. Skopp, J. Krueger, and D. Williams. 1992. DNA recognition and binding by the Euplotes telomere protein. Biochemistry 31: 10835-10843.

Putney, S.D., S.J. Benkovic, and P.R. Schimmel. 1981. A DNA fragment with an $\alpha$-phosphorothioate nucleotide at one end is asymmetrically blocked from digestion by exonuclease III and can be replicated in vivo. Proc. Natl. Acad. Sci. 78: 7350-7354.

Raghuraman, M.K. and T.R. Cech. 1989. Assembly and selfassociation of Oxytricha telomeric nucleoprotein complexes. Cell 59: 719-728.

Rawlins, D.J., M.I. Highett, and P.J. Shaw. 1991. Localization of telomeres in plant interphase nuclei by in situ hybridization and 3D confocal microscopy. Chromosoma 100: 424-431.

Romero, D.P. and E.H. Blackburn. 1991. A conserved secondary structure for telomerase RNA. Cell 67: 343-353.

Shippen-Lentz, D. and E.H. Blackburn. 1990. Functional evidence for an RNA template in telomerase. Science 247: 546552.

Tessier, L.H., P. Sondermeyer, T. Faure, D. Dreyer, A. Benavente, D. Villeval, M. Courtney, and J.P. Lecocq. 1984. The influence of mRNA primary and secondary structure on human IFN- $\gamma$ gene expression in E. coli. Nucleic Acids Res. 12: $7663-7675$.

Wang, W., R. Skopp, M. Scofield, and C.M. Price. 1992. Euplotes crassus has multiple genes encoding telomere-binding proteins and telomere-binding protein homologs. Nucleic Acids Res. 20: 6621-6629.

Whitson, P.A. and K.S. Matthews. 1986. Dissociation of the lactose repressor-operator DNA complex: Effects of size and sequence context of operator-containing DNA. Biochemistry 25: 3845-3852.

Yu, G.L. and E.H. Blackburn. 1991. Developmentally pro- grammed healing of chromosomes by telomerase in Tetrahy. mena. Cell 67: 823-832.

Yu, G.L., J.D. Bradley, L.D. Attardi, and E.H. Blackburn. 1990. In vivo alternation of telomere sequences and senescence caused by mutated Tetrahymena telomerase RNAs. Nature 344: 126-132.

Zahler, A.M. and D.M. Prescott. 1988. Telomere terminal transferase activity in the hypotrichous ciliate Oxytricha nova and a model for replication of the linear DNA molecules. Nucleic Acids Res. 16: 6953-6972.

Zakian, V.A. 1989. Structure and function of telomeres. Annu. Rev. Genet. 23: 579-604. 


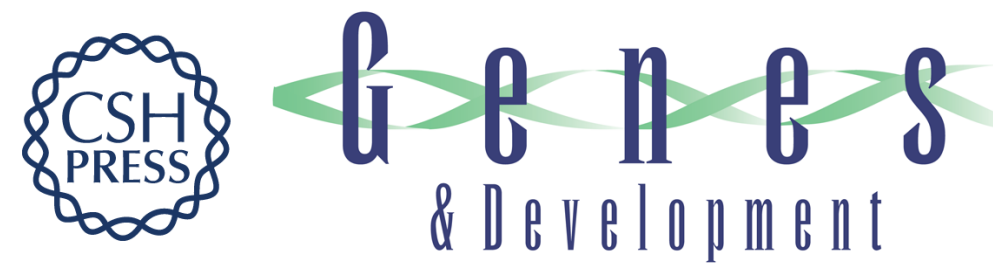

\section{Oxytricha telomere-binding protein: separable DNA-binding and dimerization domains of the alpha-subunit.}

G Fang, J T Gray and T R Cech

Genes Dev. 1993, 7:

Access the most recent version at doi:10.1101/gad.7.5.870

References This article cites 53 articles, 14 of which can be accessed free at:

http://genesdev.cshlp.org/content/7/5/870.full.html\#ref-list-1

License

Email Alerting

Service

Receive free email alerts when new articles cite this article - sign up in the box at the top right corner of the article or click here.

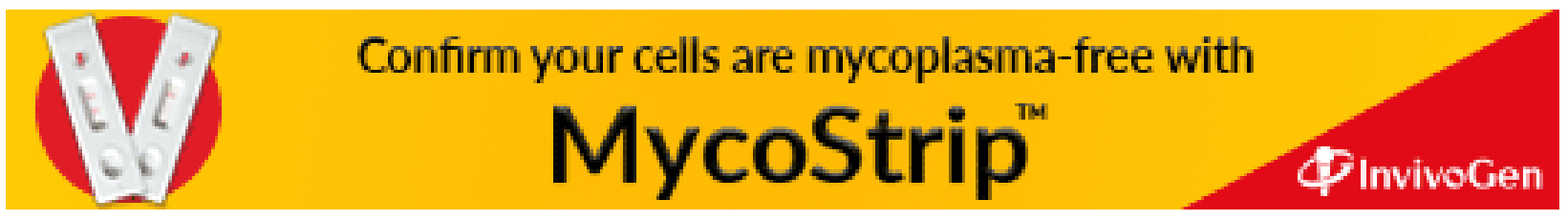

